ISSN: 2614-1280, https://jurnal.stie-aas.ac.id/index.php/IJEBAR

\title{
The Effect of Financial Performance Measured With Rentability Ratio Against Dividend Payout Ratio (Empirical Study on Manufacturing Companies group listed on BEI)
}

\author{
Imas Della Fauzi ${ }^{1}$, Rukmini ${ }^{2}$ \\ STIE AAS, Central Java, Indonesia \\ Email: rukminidra@co.id
}

\begin{abstract}
This study aims to examine whether there is a significant effect of the company's financial performance as measured by the ratio of profitability with Return on Assets (ROA), Return On Equity (ROE), Return On Investment (ROI) and Net Profit Margin (NPM) to Dividend Payout Ratio (DPR). The data collected is obtained from the financial statements of manufacturing companies listed on the Indonesia Stock Exchange period 2013-2015. The analysis used to know how big the influence of ROA, ROE, ROI NPM to DPR company, writer do statistical analysis done by using descriptive analysis, doubled linear regression, correlation coefficient and coefficient of determination. While testing the hypothesis using F test for simultaneous test and t test partially, using SPSS 16. Based on the results of data processing, obtained regression equation $\mathrm{Y}=31.225+1.209 \mathrm{X}_{1}-0.106$ $\mathrm{X}_{2}+0.505 \mathrm{X}_{3}-0.708 \mathrm{X}_{4}+\varepsilon$, analysis results Statistics simultaneously obtained the value of determination coefficient of $28.3 \%$. While the rest equal to $71.7 \%$ influenced by other factors. Based on hypothesis test by using significant level $\alpha$ $=0,05$ result of $F$ test, show that together regression model can be used to explain the relation between Return on Asset, Return On Equity, Return On Investment and Net Profit Margin to Dividend Payout Ratio.
\end{abstract}

Keywords: Return on Assets, Return on Equity, Return On Investment and Net Profit Margin, Dividend Payout Ratio

\section{Introduction}

In Indonesia, every company is certainly not spared from global competition that can make an opportunity or can be a threat to the company if not anticipate before. Included are manufacturing companies listed on the BEI. In this case the capital market has an important role as an effective means to raise funds even more for companies that need capital for longterm financing investment. Before investing, investors should consider the condition of the company that can be seen from the performance of manufacturing companies listed on the Indonesia Stock Exchange (BEI), exchange rate fluctuations, transaction volume, stock conditions, and environmental conditions of the company is located.

The required information is a company performance report that is reflected in the financial statements. To measure the financial performance of a company can use financial ratios such as liquidity ratios, activity ratios, profitability/profitability ratios, solvency ratios and market ratios.

The proportion of dividends paid to shareholders depends on the ability of the company to generate profits and the form of dividend policy applied by the company concerned. Stocks with large dividends are one of the most attractive factors for investors that can raise stock prices. In line with the increasing dividend given, it is expected that the level of financial performance measured by profitability or 
ISSN: 2614-1280, https://jurnal.stie-aas.ac.id/index.php/IJEBAR

profitability ratios grows higher in the ability to generate profits. Accordingly, in this study the author took the title: "The Effect of Financial Performance Measured With Rentability Ratio Against Dividend Payout Ratio" (Empirical Study on Manufacturing Companies group listed on BEI).

\section{Theoretical Review}

\subsection{Underlying Theory}

\section{a. Financial performance}

Performance derived from the word performance, performance is expressed as achievements achieved by the company within a certain period that reflects the level of health of the company. Understanding Financial Performance by Fahmi (2011: 2), is "Financial performance is an analysis conducted to see how far a company has implemented by using the rules of financial implementation properly and correctly.

1) Performance Measurement

The company's financial performance is closely related to the measurement and performance appraisal. Performance measurement (performance measurement) is the qualification and efficiency and effectiveness of the company in business operations during the accounting period.

The performance assessment according to Sri mindarti (2006: 34) is the determination of operational effectiveness, organization, and employees based on the targets, standards and criteria that have been previously set periodically. Performance measurement is used by the company to make improvements over its operational activities in order to compete with other companies. Financial performance analysis is a critical review process to review data, calculate, measure, interpret, and provide solutions to the company's finances in a certain period.

\section{2) Analisis Kinerja Keuangan}

Financial performance can be assessed with multiple analytical tools. Based on the technique, financial analysis can be differentiated into (Jumingan, 2006: 242)

a) Comparative Analysis of Financial Statements, is an analytical technique by comparing the financial statements of two or more periods by showing changes, both in the number (absolute) and in percentage (relative).

b) Analysis of Trends (tendency position), is an analysis technique to determine whether the financial condition tendency shows an increase or decrease.

c) Percentage Analysis of Component (common size), is an analytical technique to determine the percentage of investment in each asset to the total or total assets and debt.

d) Analysis of Sources and Use of Working Capital, an analytical technique to determine the amount of sources and use of working capital through two time periods are compared.

e) Analysis of Sources and Use of Cash, is an analytical technique to determine the condition of cash 
ISSN: 2614-1280, https://jurnal.stie-aas.ac.id/index.php/IJEBAR

accompanied by the cause of cash changes in a certain period of time.

f) Financial Ratio Analysis, is a financial analysis technique to determine the relationship between certain posts in the balance sheet and income statement either individually or simultaneously.

g) Gross Profit Change Analysis, an analytical technique to determine the position of profit and the causes of changes in earnings.

h) Break Even analysis, an analysis technique to determine the level of sales to be achieved so that companies do not experience losses.

\section{3) Financial Performance Assessment}

For investors, information about the company's financial performance can be used to see if they will keep their investment in the company or look for other alternatives. If the company's performance is good then the business value will be high. With high business value makes investors glance at the company to invest its capital so that there will be an increase in stock prices. Or it can be said that stock price is a function of company value.

\section{b. Financial statements}

The financial statements are the end result of the accounting process prepared in accordance with generally accepted accounting principles. The financial statements are the responsibilities that have been entrusted to him. The financial condition and results of the operations of the company as reflected in the financial statements may reflect the performance or financial performance of the competing firm.

1) Types of Financial Statements

a) Balance Sheet

A balance sheet is a financial statement that provides information about a company's financial position at a given moment. To be able to describe the company's financial position at a given moment, the balance sheet has three elements of the financial statements of assets, liabilities, and equity.

b) Statements of Profit and Loss

The income statement has two elements in generating profit during the period of performance that is: (Dwi Prastowo and Rifka Julianty, 2002: 20). Income is a form of increase in economic benefits in the form of income or increase in assets or decrease in liabilities. For example interest income, rent, service income.

c) Expense is the decrease of economic benefits in the outflow of assets or liabilities. For example: salary and wages, depreciation, cost of goods sold.

2) Statements of changes in equity

According to IAI (2007: 1.12), the Company must present the statement of changes in equity as a major component of the financial statements, showing the related period's profit or loss, the accumulated balance of profit or loss at the beginning and end of the period and its amendments. 
3) Statement of cash flows

According to IAI (2007: 2.2), that cash flow is the inflow and outflow of cash or cash equivalents.

According to IAI (2007: 1.13) records on financial statements should be presented systematically. Each item in the balance sheet, income statement and cash flow statement must relate to the information contained in the notes to the financial statements. Notes to financial statements disclose: information on the basis of the preparation of financial statements and accounting policies that are selected and applied to the events and transactions that are important, the information required in the statement of financial accounting standards but not presented in the balance sheet, income statement, cash flow statements and reports changes in equity, additional information not presented in the financial statements but required in a fair presentation.

4) Objectives of Financial Statements

a) Provide information regarding the financial position, performance and changes in the financial position of a company that is beneficial to a large number of users in decision making.

b) Financial statements prepared for this purpose meet the common needs of most users. However, the financial statements do not provide all the information the user needs in economic decision making as it generally describes the financial effects of past activities, and is not required to provide financial information. c) The financial statements indicate what management has done, or management's liability for the resources entrusted to it. Users who want to assess what has been done or accountable. Management does so in order to meet their economic decisions.

5) Limitations of Financial Statements According Munawir (2004: 6), states that the financial statements are historical and comprehensive and as a progress report. The financial statements consist of data which results from a combination of recorded facts, principles, and habits in accounting and personal opinion.

Limitations of financial statements according to Harahap (2004: 17-18), are:

a) The financial statements are historical, which is a report on past events. Hence the financial statements cannot be considered as the only source of information in the economic decision-making process, let alone to forecast the future of the value of the company today.

b) The financial statements are general and do not want to meet the needs of certain parties or special parties as the buyers.

c) The process of preparing the financial statements does not escape the use of estimates and various considerations.

d) Financial statements prepared by technical terms and users of financial statements are assumed to understand the technical language of accounting and the nature of the information reported. 
ISSN: 2614-1280, https://jurnal.stie-aas.ac.id/index.php/IJEBAR

e) The existence of various alternative accounting methods that can be used to cause variations in the measurement of economic resources and the level of success between companies. inventory valuation methods may use LIFO, FIFO, and Average Similarly depreciation method: straight line, declining balance, Sum of Year Digit and so on.

\section{c. The notion of Ratio}

Ratio is a tool that can be used to explain the relationship between two kinds of financial data. The ratio describes a relationship or balance (mathematical relationship) between a certain amounts to another amount (Munawir, 2000: 54). The actual ratio is only the tool stated in the arithmetical terms that can be used to explain the relationship between two kinds of financial data (Bambang Riyanto, 2001: 329). Financial ratios represent information that describes the relationship between the various accounts (accounts) of financial statements that reflect the financial condition and the results of the company's operations.

In this study the authors limit using only a few ratios of the existing profitability ratios, among others:

1) Return on Equity (ROE)

Return on Equity (ROE) is one way to calculate the efficiency of a company by comparing the profit available to the owner of the capital itself with the amount of own capital that generates the profit. According to Agus Sartono (2003: 123) ROE is a measure of the ability of a company to obtain profits available to shareholders of the company. This ratio is influenced by the size of the company's capital, the greater the capital proportion then the better ROE as well.

$$
\mathrm{ROE}=\frac{\text { Net profit after tax } \mathrm{x} 100 \%}{\text { Total Equity }}
$$

2) Return on Asset (ROA)

Return on Assets (ROA) is the ratio used to measure the effectiveness of companies in generating profits by utilizing the assets they have (Febrianti, 2014). ROA or ROI is obtained by comparing the net income after tax (NIAT) to average total assets. The greater the profits of the company would be the dividend as the income is paid even greater.

ROE $=\frac{\text { Net profit after tax x } 100 \%}{\text { Total assets }}$

3) Net Profit Margin (NPM)

Net Profit Margin (NPM) menggambarkan besarnya presentase keuntungan bersih yang diperoleh perusahaan untuk setiap penjualan karena memasukkan semua unsur pendapatan dan biaya. Rasio ini juga bermanfaat untuk mengukur tingkat efisiensi total pengeluaran biaya-biaya dalam perusahaan.

$$
\mathrm{NPM}=\frac{\text { Net income } \times 100 \%}{\text { Sales }}
$$

\section{4) Return on Investment (ROI)}

Return on Investment (ROI) is a ratio that measures the ability of the company with the overall funds invested in the assets used for the company's operations in an attempt to generate profits. Mulyadi (2001: 440), argued that the ROI is the ratio of earnings with the investment used to 
ISSN: 2614-1280, https://jurnal.stie-aas.ac.id/index.php/IJEBAR

generate profit. The formula for calculating ROI is:

$$
\begin{aligned}
& - \text { ROI }=\frac{\text { laba X 100\% }}{\text { Investasi }} \\
& - \text { ROI }=\frac{\text { Pendapatan }}{\text { Investasi }} \times \frac{\text { Laba }}{\text { Pendapatan }}
\end{aligned}
$$

In formula 1, for the measurement of profit center performance, the profit to be earned by a profit center within a given time period divided by the investment which will be used for the earnings. Formula 2, both investment and profit are calculated by revenue. Investments associated with income indicate the level of invocative turnover in a given period. The rate of investment turnover shows the productivity of investment use in generating revenue. Profit divided by revenue shows profit margin which is the percentage of earnings that can be obtained from every rupiah income.

d. Dividend

Dividends are the value of the company's net income after tax minus retained earnings retained as reserves (Ang, 1997). According to Hanafi (2004), dividends are compensation received by shareholders, in addition to capital gains.

1) Dividend Policy

The dividend policy is the distribution of corporate profits to investors whose value depends on the policy of the company concerned, which may result in reduced retained earnings for the company (Efni, 2013). This dividend policy is one of the most important things in the company because it involves two parties with different interests, insiders and investors.m
Therefore, companies should implement an optimal dividend policy with current dividend stability and future growth of companies by maximizing stock prices. The dividend policy in this study is proxies by dividend payout ratio (DPR).

2) Divident Payout Ratio

Dividends paid can be classified as financing cash flow because it is the cost of obtaining financial resources. The share of the profits distributed to shareholders is called dividend payout. According to Henry Simamora (2000: 523), suggests that the Dividend Payout Ratio is a percentage of ordinary share earnings paid in the form of dividends.

$$
\begin{aligned}
\text { DPR }= & \frac{\text { DPS X } 100 \%}{\text { EPS }} \\
& \text { Infor,ation: } \\
& \text { DPR: Dividend Payout Ratio } \\
& \text { DPS: Dividen per share } \\
& \text { EPS: Earnings per share }
\end{aligned}
$$

3) Factors affecting dividend policy Factors influencing dividend policy (Ridwan \& Inge, 2003: 387), among others:

a) The rule of law

-Regulations concerning net income determine that dividends may be from earnings of past years and current year.

-Rules concerning actions that harm the capital. Protecting creditors by prohibiting payment of dividends from capital.

b) Liquidity position

Retained earnings are usually invested in the form of assets needed 
to run a business. Therefore, if the company gets a lot of profits it may not be able to pay dividends because of its liquidity. In this situation the company may decide not to pay dividends in cash.

c) Pay the loan

If the company obtains a loan to expand the company, then the company can repay the loan.

d) Loan contract

Short-term or long-term loan contracts often limit the company's ability to repay loans.

e) Restrictions on prefern shares

If the dividend oemegang prefern share has not been paid then the dividend payout to ordinary shareholders can not be done.

f) The need for funds for investment A growing company always needs new funds to invest in profitable projects. In this case management tend to prefer to use retained earnings because the utilization of retained earnings does not require flotation cost.

g) Fluctuations in earnings

If the company fluctuates in a smaller dividend it is done to maintain the stability of dividend payments. With fluctuating profits the company also does not use much debt as a source of funding, this is done to reduce the risk of bankruptcy.

\section{e. Effect of Financial Performance on Dividend Payout Ratio}

The financial performance of the company is very influential on the dividend payout. This can be seen from the dividend policy that is highly dependent on financial performance especially seen from the ratio of profitability. Dividend policy is important information for shareholders to see the financial performance of a company itself.

\subsection{Research Conducted}

The research conducted by the authors refers to research conducted by: The first study that is from research Sulhan Faris (2012) with the title Analysis Influence of Financial Ratio and Non-Financial Ratios To Policy Dividend Payout Ratio (Study on Manufacturing Companies Listed on BEI period 2008-2010 ). In this research, Liquidity and Profitability variable have positive and significant effect to dividend payout ratio.

The Growth variable shows a negative and significant influence on the dividend payout ratio. Firm size variable has positive and not significant effect on dividend payout ratio. The insider ownership variable shows the negative and significant influence on the dividend payout ratio and the instituonal ownership variable has a negative and insignificant effect on the dividend payout ratio. The second research is Bryan Aristanto (2015) Factor Analysis Affecting Dividend Payout Ratio (Case Study on Manufakur Company Listed on BEI Year 2011-2013).

The result of his research stated that the variable of Insider Ownership and Debt to Equity Ratio have no significant negative effect to Dividend Payout Ratio. While Return On Asset and Firm Size have positive significant effect to Dividend Payout Ratio. Insider Ownership variables, 
International Journal of Economics, Business and Accounting Research (IJEBAR)

Peer Reviewed - International Journal

Vol-2, Issue-1, 2018 (IJEBAR)

ISSN: 2614-1280, https://jurnal.stie-aas.ac.id/index.php/IJEBAR

Debt to Equity Ratio, Return On Assets, and Firm Size together have a significant influence on Dividend Payout Ratio.

The third study is Nuriyatul Mashumah (2015) entitled Factors Affecting Dividend Payout Ratio In Companies That Enter In List Of Sharia Securities. In this research found that together regression model can be used to explain the relationship between earnings per share, size, growth, dept to equity ratio, return on assets and cash ratio to dividend payout ratio. Partially variable earning per share, dept to equity ratio and cash ratio have influence and negative relation to dividend payout ratio. Variable size and return on assets have no effect on dividend payout ratio but have a positive relationship. While the variable growth has no effect and has a negative relationship with devidend payout ratio.

\subsection{Theoretical Framework}

The systematic framework in this research can be described as follows:

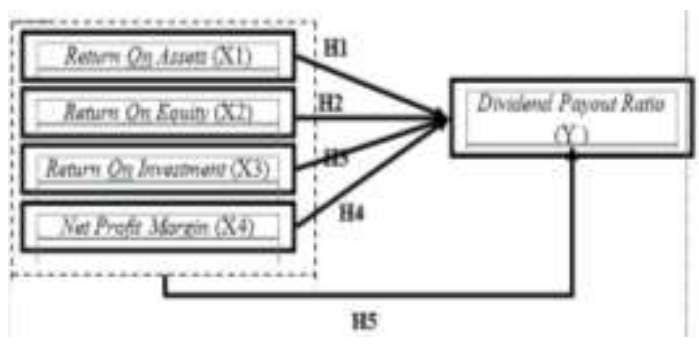

Figure 2.1

Theoretical Framework

\subsection{Hypothesis}

a. Influence of ROA to Dividend Payout Ratio (DPR)

H1: Return on Assets has positive effect on Dividend Payout Ratio.

b. The Effect of Return on Equity on Dividend Payout Ratio (DPR)
H2: Return on Equity has a positive effect on Dividend Payout Ratio.

c. Effect of Return on Investment on Dividend Payout Ratio (DPR)

H3: Return On Investment has a positive effect on Dividend Payout Ratio.

d. Effect of NPM on Dividend Payout Ratio (DPR)

H4: Net Profit Margin positively affects Dividend Payout Ratio

e. Effect of Return on Equity, Net Profit Margin, Return on Investment and Return on Assets to Dividend Payout Ratio simultaneously.

H5: There is a significant influence between Return on Equity, Net Profit Margin, Return on Investment and Return on Assets to Dividend Payout Ratio simultaneously.

\section{Research Methodology}

In this study the population observed is a group of companies whose shares are listed in Indonesia Stock Exchange (IDX) period 2013-2015. Especially in the manufacturing industry group based on this research, there are 143 companies from 19 industry sectors. Sampling in this research is done by purposive sampling.

Types and sources of data used in this study are secondary data containing annual financial statements both published by manufacturing companies listed on the Stock Exchange during the period 20132015. The data of this research is obtained through Indonesia Stock Exchange (BEI) website, www.idx.co.id and Indonesian Capital Market Directory (ICMD). Other literature is derived from books, research journals, theses, articles, and news. 
International Journal of Economics, Business and Accounting Research (IJEBAR)

Peer Reviewed - International Journal

Vol-2, Issue-1, 2018 (IJEBAR)

ISSN: 2614-1280, https://jurnal.stie-aas.ac.id/index.php/IJEBAR

\section{Results and Discussion}

\subsection{Description of Research Object}

A manufacturing company is a company that processes raw materials to turn into ready-to-market goods. All the processes that occur in this industry generally involve a variety of modern equipment. Manufacturing companies are currently growing very rapidly every year both in terms of financial statements and shares that have gone public.

The business prospects in manufacturing also prove to be very profitable each year which will attract investors to invest in the company. The object of research used in this study is a manufacturing company listed on the BEI from 2013-2015.

\section{a. Descriptive Statistics of Research Variables}

Based on data inputted from ICMD 2015 and Annual Report 2016) it can be calculated the financial ratios used in this study include ROA, ROE, ROI, NPM. Here is a statistical description of each variable.

Based on the calculation in Table 4.2 there are 15 sample companies from 45 observation data. The ROA, ROE, ROI, NPM and DPR variables during the observation period 2013-2015 show that the standard deviation value is smaller than the average.

Where the ROA averageb during the observation period is 16.1211 with the standard deviation (SD) of 11.92167 and the minimum value of 1.15 and the maximum value of 65.72 . The mean of ROE during the observation period of 27.2044 with standard deviation (SD) of 27.83963 and the minimum value of 2.36 and the maximum value of 143.53 .
Average (mean) ROI during the observation period of 30.8104 with standard deviation (SD) of 22.49031 and minimum value of 0.08 and the maximum value of 88.16.

Average (mean) NPM during observation period of 13.1562 with standard deviation (SD) of 7.37634 and minimum value of 2.16 and maximum value of 32.88. For the average value (mean) of DPR variables during the observation period of 54.0671 with standard deviation (SD) of 29.23172 and minimum value of 0.08 and the maximum value of 145.92. The results show that the standard deviation (SD) value is less than the average. Similarly, the minimum value smaller than the average and the maximum value greater than the average indicates that the data of ROA, ROE, ROI, NPM and DPR variables indicate good results.

It can be seen that the value of ROA in 2013-2015 from the 15 companies that become the sample, the maximum value of 65.72 is experienced by PT. Multi Bintang Indonesia Tbk in 2013. The lowest ROA value is experienced by PT Holcim Indonesia Tbk in 2015 with minimum value of 1.15 . On a large ROE, the minimum value of 2.36 is met by PT Holcim Indonesia Tbk in 2015, and the maximum value of 143.53 is experienced by PT Multi Bintang Indonesia Tbk in 2014. For the value of ROI, the minimum value of 0.08 is experienced by PT Multi Bintang Indonesia Tbk in 2014 and the value maximum of 88.16 in 2013. The minimum value of NPM of 2.16 is covered by PT Holcim Indonesia Tbk in 2015 and its maximum value of 32.88 is experienced by PT Multi Bintang Indonesia Tbk in 2013. While in the DPR minimum value of 
International Journal of Economics, Business and Accounting Research (IJEBAR)

Peer Reviewed - International Journal

Vol-2, Issue-1, 2018 (IJEBAR)

ISSN: 2614-1280, https://jurnal.stie-aas.ac.id/index.php/IJEBAR

0.08 experienced by PT Merck Tbk in 2013, and its maximum value of 145.92 experienced by PT Multi Bintang Indonesia Tbk in 2015.

\subsection{Classical Assumption Testing}

\section{Results}

From the calculation of the average sample of financial ratios for five years, then in this study it is necessary to test the classical assumptions in advance which include: normality test, multicollinearity test, heteroscedasticity test and autocorrelation test performed as follows:

a) Normality Test

The following is the result of residual normality test of independent variables ROA, ROE, ROI and NPM and dependent variable of DPR. To find out it is used Kolmogorov-Smirnov Test using significance level> 0.05 .

Table 4.3

Normality Test Results

\begin{tabular}{|l|l|r|}
\hline \multicolumn{2}{|c|}{ One-Sample Kolmogorov-Smirnov Test } \\
\hline \multicolumn{2}{|l|}{} & $\begin{array}{c}\text { Unstandardized } \\
\text { Residual }\end{array}$ \\
\hline $\mathrm{N}$ & 45 \\
\hline Normal Parameters & & .0000000 \\
\hline \multirow{2}{*}{$\begin{array}{l}\text { Most Extreme } \\
\text { Differences }\end{array}$} & Mean & .113 \\
\cline { 2 - 3 } & Std. Deviation & 24.75143296 \\
\cline { 2 - 3 } & Absolute & .113 \\
\cline { 2 - 3 } & Positive &. .102 \\
\hline \multicolumn{2}{|l|}{ Kolmogorov-Smirnov Z } & .757 \\
\hline Asymp. Sig. (2-tailed) & .616 \\
\hline a. Test distribution is Normal. & \\
\hline
\end{tabular}

Based on the test results in table 4.3 above shows the acquisition of sigma K-S (value $\alpha$ ) from Kolmogorov Smirnov test results note that the significance value of 0.616 is greater than 0.05 , so it can be concluded that the data we tested normally distributed. Test of Multicollonearity
To detect the presence or absence of symptoms of multicollonearity between independent variables used Variance Inflation Factor (VIF) and Tolerance.

Table 4.4

Multicollonearity Test Results

\begin{tabular}{|c|c|c|c|c|c|c|c|c|}
\hline \multicolumn{9}{|c|}{ Coefficients $^{\mathrm{a}}$} \\
\hline \multirow{2}{*}{\multicolumn{2}{|c|}{ Model }} & \multicolumn{2}{|c|}{$\begin{array}{c}\text { Unstandardiz } \\
\text { ed } \\
\text { Coefficients }\end{array}$} & \multirow{2}{*}{$\begin{array}{c}\text { Standar } \\
\text { dized } \\
\text { Coeffic } \\
\text { ients } \\
\text { Beta }\end{array}$} & \multirow[t]{2}{*}{$\mathrm{T}$} & \multirow[t]{2}{*}{ Sig. } & \multicolumn{2}{|c|}{$\begin{array}{c}\text { Collinearity } \\
\text { Statistics }\end{array}$} \\
\hline & & B & $\begin{array}{l}\text { Std. } \\
\text { Error }\end{array}$ & & & & $\begin{array}{l}\text { Toler } \\
\text { ance }\end{array}$ & VIF \\
\hline \multirow[t]{5}{*}{1} & $\begin{array}{l}\text { (Co } \\
\text { nsta } \\
\text { nt) }\end{array}$ & $\begin{array}{r}31.2 \\
25\end{array}$ & $\begin{array}{r}9.12 \\
7\end{array}$ & & $\begin{array}{r}3.42 \\
1\end{array}$ & .001 & & \\
\hline & $\mathrm{X}_{1}$ & $\begin{array}{r}1.20 \\
9 \\
\end{array}$ & .795 & .493 & $\begin{array}{r}1.52 \\
1 \\
\end{array}$ & .136 & .171 & $\begin{array}{r}5.8 \\
63 \\
\end{array}$ \\
\hline & $\mathrm{X}_{2}$ & $.106^{-}$ & .284 & -.101 &. & .713 & .244 & $\begin{array}{r}4.0 \\
95 \\
\end{array}$ \\
\hline & $\mathrm{X}_{3}$ & .505 & .179 & .388 & $\begin{array}{r}2.81 \\
3 \\
\end{array}$ & .008 & .941 & $\begin{array}{r}1.0 \\
63 \\
\end{array}$ \\
\hline & $\overline{X_{4}}$ & $.708^{-}$ & .805 & -.179 & $\begin{array}{r}- \\
.880 \\
\end{array}$ & .384 & .434 & $\begin{array}{r}2.3 \\
02 \\
\end{array}$ \\
\hline & epe & nt Var & ble: Y & & & & & \\
\hline
\end{tabular}

Source: Secondary data processed, 2017; output of SPSS version 16

Based on the test results in table 4.4 above note that the tolerance values of ROA (X1), ROE (X2), ROI (X3) and NPM (X4) variables are $0.171,0.244$, 0.941 and 0.434 greater than 0.10 . While the VIF value of the variable, ROE (X2), ROI (X3), NPM (X4) i.e $5.863,4,095,1.063$ and 2.302 smaller than 10. Thus it can be concluded ROA, ROE, ROI and NPM variables do not occur multicollinierity.

b) Heteroscedasticity Test

This test aims to test whether the regression model of variance inequality occurs from one observation to another observation. 
International Journal of Economics, Business and Accounting Research (IJEBAR)

Peer Reviewed - International Journal

Vol-2, Issue-1, 2018 (IJEBAR)

ISSN: 2614-1280, https://jurnal.stie-aas.ac.id/index.php/IJEBAR

Table 4.5

Heteroscedasticity Test Results

\begin{tabular}{|c|c|c|c|c|c|c|}
\hline \multicolumn{7}{|c|}{ Coefficients $^{\mathrm{a}}$} \\
\hline \multirow{2}{*}{\multicolumn{2}{|c|}{ Model }} & \multicolumn{2}{|c|}{$\begin{array}{l}\text { Unstandardized } \\
\text { Coefficients }\end{array}$} & \multirow{2}{*}{$\begin{array}{c}\text { Standardized } \\
\text { Coefficients } \\
\text { Beta }\end{array}$} & \multirow[t]{2}{*}{$\mathrm{t}$} & \multirow[t]{2}{*}{ Sig. } \\
\hline & & $\mathrm{B}$ & $\begin{array}{c}\text { Std. } \\
\text { Error }\end{array}$ & & & \\
\hline \multirow[t]{5}{*}{1} & $\begin{array}{l}\text { (Co } \\
\text { nsta } \\
\text { nt) }\end{array}$ & $\begin{array}{r}7.57 \\
0\end{array}$ & 5.206 & & $\begin{array}{r}1.45 \\
4\end{array}$ & .154 \\
\hline & $\mathrm{X}_{1}$ & .516 & 453 & .374 & $\begin{array}{r}1.13 \\
8\end{array}$ & 262 \\
\hline & $\mathrm{X}_{2}$ & .115 & .162 & 195 & .710 & 482 \\
\hline & $X_{3}$ & .044 & .102 & .060 & 428 & 671 \\
\hline & $\mathrm{X}_{4}$ & -.159 & .459 & -.071 & -.345 & .732 \\
\hline & epens & t Varia & RES2 & & & \\
\hline
\end{tabular}

Source: Secondary data processed, 2017; output of SPSS version 16

Based on the test results in table 4.5 above, it is known that the sig value of ROA (X1), ROE (X2), ROI (X3) and NPM (X4) variables are $0.262,0.482$, $0.671,0.732$ greater than 0.05 , heteroscedasticity occurs.

c) Autocorrelation Test

The purpose of this test is to determine whether there is correlation between members of the observations arranged according to the time series.

Table 4.6

Autocorrelation Test Results

\begin{tabular}{|l|r|}
\hline \multicolumn{2}{|c|}{ Runs Test } \\
\hline & \multicolumn{1}{|c|}{ Unstandardized Residual } \\
\hline Test Value $^{\mathrm{a}}$ & -4.96578 \\
\hline Cases $<$ Test Value & 22 \\
\hline Cases >= Test Value & 23 \\
\hline Total Cases & 45 \\
\hline Number of Runs & 26 \\
\hline Z & .607 \\
\hline Asymp. Sig. (2-tailed) & .544 \\
\hline a. Median & \\
\hline \multicolumn{2}{|c|}{ Source: Secondary Data processed 2017; outpus } \\
SPSS version 16
\end{tabular}

Based on the test results in Table 4.6 above note that the value of Asymp. Sig. (2-tailed) of $0.544>$ greater than 0,05 , it can be concluded that there are no symptoms or problems of autocorrelation.

\subsection{Multiple Linear Regression Test}

The results of this calculation explain the closeness of the relationship between ROA, ROE, ROI and NPM variables with DPR variables. The rresult of the data if using SPSS V 16.0 obtained multiple correlation values and other measures as follows:

Table 4.7

Results of Multiple Linear Regression Test

\begin{tabular}{|c|c|c|c|c|c|c|}
\hline & & & Coeffic & $\mathrm{nts}^{\mathrm{a}}$ & & \\
\hline & & $\begin{array}{l}\text { Unstan } \\
\text { d Coef }\end{array}$ & $\begin{array}{l}\text { ardize } \\
\text { icients }\end{array}$ & $\begin{array}{c}\text { Standar } \\
\text { dized }\end{array}$ & $\mathrm{t}$ & Sig. \\
\hline & & B & $\begin{array}{l}\text { Std. } \\
\text { Error }\end{array}$ & Beta & & \\
\hline 1 & $\begin{array}{l}\mathrm{Co} \\
\text { nsta } \\
\text { nt) }\end{array}$ & $\begin{array}{r}31.22 \\
5\end{array}$ & 9.127 & & 3.421 & .001 \\
\hline & $\mathrm{X} 1$ & 1.209 & .795 & .493 & 1.521 & .136 \\
\hline & $\mathrm{X} 2$ & -.106 & .284 & -.101 & -.371 & .713 \\
\hline & X3 & .505 & .179 & .388 & 2.813 & .008 \\
\hline & $\mathrm{X} 4$ & -.708 & .805 & -.179 & -.880 & .384 \\
\hline & epenc & t Varia & e: Y & & & \\
\hline
\end{tabular}

Based on the calculation above, it obtained multiple linear regression equation:

$$
\begin{aligned}
& Y=31.225+1.209 X_{1}-0.106 X_{2}+ \\
& 0.505 X_{3}-0.708 X_{4}+\varepsilon
\end{aligned}
$$

The equation above can be interpreted as follows:

a. Intercept or constant is 31.225 is Intercept value means that the regression line intersects $\mathrm{Y}$ axis at point 31.225 and is also the value of the dependent variable of estimation when $\mathrm{X}, \mathrm{X}, \mathrm{X}$, and $\mathrm{X}$ are equal to zero. Without ROA variable, ROE, ROI, NPM magnitude of House 31.225. 
ISSN: 2614-1280, https://jurnal.stie-aas.ac.id/index.php/IJEBAR

b. Regression coefficient of 1,209 marked positive states that every $1 \%$ ROA increase will increase the House of $1,209 \%$ assuming other $\mathrm{X}$ variables are constant.

c. Regression coefficient of - 0.106 with negative sign states that every increase of ROE by $1 \%$ will lower the House of $0106 \%$ assuming other variable $\mathrm{X}$ constant.

d. Regression coefficient of 0,505 marked positive states that any increase in ROI of $1 \%$ will increase the House of $0.505 \%$ assuming other $\mathrm{X}$ variables are

\begin{tabular}{|c|c|c|c|c|c|c|}
\hline \multicolumn{7}{|c|}{$\begin{array}{ll}\text { Table } 4.8 \\
\end{array}$} \\
\hline \multirow{2}{*}{\multicolumn{2}{|c|}{ Model }} & \multicolumn{2}{|c|}{$\begin{array}{c}\text { Unstandardized } \\
\text { Coefficients }\end{array}$} & \multirow{2}{*}{$\begin{array}{c}\begin{array}{c}\text { Standardi } \\
\text { zed } \\
\text { Coefficie } \\
\text { nts }\end{array} \\
\text { Beta }\end{array}$} & \multirow[t]{2}{*}{$\mathrm{t}$} & \multirow[t]{2}{*}{ Sig. } \\
\hline & & B & $\begin{array}{c}\text { Std. } \\
\text { Error }\end{array}$ & & & \\
\hline \multirow[t]{5}{*}{1} & $\begin{array}{l}\text { (Const } \\
\text { ant) }\end{array}$ & $\begin{array}{r}31.2 \\
25\end{array}$ & 9.127 & & $\begin{array}{r}3.42 \\
1\end{array}$ & .001 \\
\hline & $\mathrm{X} 1$ & $\begin{array}{r}1.20 \\
9\end{array}$ & .795 & .493 & $\begin{array}{r}1.52 \\
1\end{array}$ & .136 \\
\hline & $\mathrm{X} 2$ & -.106 & .284 & -.101 & -.371 & .713 \\
\hline & $\mathrm{X} 3$ & .505 & 179 & .388 & 2.81 & .008 \\
\hline & $\mathrm{X} 4$ & -.708 & .805 & $\begin{array}{l}-.179 \\
\end{array}$ & -.880 & .384 \\
\hline
\end{tabular}
constant.

e. Regression coefficient of - 0.708 is negative signified that every increase of NPM of $1 \%$ will decrease the House of equal to $-0.708 \%$ assuming other variable $\mathrm{X}$ constant.

\subsection{Hypothesis Testing Results}

The results of multiple linear regression calculations above cannot be used as the basis of conclusions, therefore required a test of the significance of the model, either partially or simultaneously.

a) Test $t$ (Partial effect test)

The hypothesis of the $t$ test are:
Ho: $r_{1}=0$ There is no significant influence between ROA on DPR.

Ha: $r_{1} \neq 0$ There is a significant influence between ROA on DPR.

Ho: $r_{1}=0$ There is no significant influence between ROE on DPR.

Ha: $r_{1} \neq 0$ There is a significant influence between ROE on DPR.

Ho: $r_{1}=0$ There is no significant influence between ROI and DPR.

Ha: $r_{1} \neq 0$ There is a significant influence between ROI and DPR.

Ho: $r_{1}=0$ There is no significant influence between NPM on DPR.

Ha: $r_{1} \neq 0$ There is a significant influence between NPM on DPR.

The level of confidence used is $95 \%$ then the value of $\alpha=0.05$. Basic decisionmaking in test i.e 1. $\mathrm{H} 0$ accepted and $\mathrm{Ha}$ rejected if the value of $\mathrm{t}$ arithmetic $<\mathrm{t}$ table or if the value of Sig. > 0, 05, 2. H0 rejected and Ha accepted if the value of $t$ arithmetic $>t$ table or if the value of Sig. $<0,05$. Then the test can be done partially as follows:

a. From the results of partial test calculations obtained value of $t$ arithmetic $1.521<\mathrm{t}$ table 2.02108 and significant value of $0.136>0.05$, then Ho accepted $\mathrm{Ha}$ rejected this means there is no significant influence between the variable ROA $\left(\mathrm{X}_{1}\right)$ to the variable changes DPR .

b. From the results of partial test calculations obtained value of $t$ arithmetic - $0.371<\mathrm{t}$ table 2.02108 and significant value of $0.713>0.05$, then Ho accepted $\mathrm{Ha}$ rejected this means there is no significant influence 
International Journal of Economics, Business and Accounting Research (IJEBAR)

Peer Reviewed - International Journal

Vol-2, Issue-1, 2018 (IJEBAR)

ISSN: 2614-1280, https://jurnal.stie-aas.ac.id/index.php/IJEBAR

\begin{tabular}{|c|c|c|c|c|c|}
\hline Dete & $\begin{array}{r}\text { Iina } \\
(\mathrm{F}\end{array}$ & $\begin{array}{l}\text { T: } \\
\text { ion }( \\
\text { Mo }\end{array}$ & $\begin{array}{l}\text { el } 4.10 \\
\text { efficien } \\
\text { el Summ }\end{array}$ & $\begin{array}{l}\text { Test } \\
\text { ry }\end{array}$ & sult \\
\hline $\begin{array}{l}\text { Mod } \\
\text { el }\end{array}$ & $\mathrm{R}$ & $\begin{array}{c}\mathrm{R} \\
\mathrm{Sq} \\
\text { uar }\end{array}$ & $\begin{array}{l}\text { Adjuste } \\
\text { d R } \\
\text { Square }\end{array}$ & $\begin{array}{l}\text { Std. } \\
\text { of } \\
\text { Esti }\end{array}$ & $\begin{array}{l}\text { Error } \\
\text { he } \\
\text { nate }\end{array}$ \\
\hline 1 & $\begin{array}{r}.53 \\
2^{\mathrm{a}}\end{array}$ & $\begin{array}{r}.28 \\
3\end{array}$ & & 211 & $\begin{array}{r}25.9 \\
5952\end{array}$ \\
\hline $\begin{array}{l}\text { a. } \operatorname{Pr} \\
\mathrm{X} 2,2\end{array}$ & & & $\operatorname{stant})$ & X3, & \\
\hline
\end{tabular}

between variable $\mathrm{ROE}\left(\mathrm{X}_{2}\right)$ on changes in variables DPR.

c. From the results of partial test calculation obtained $\mathrm{t}$ value 2.813> $\mathrm{t}$ table 2.02108 and significant value of $0.008<0.05$ with a coefficient marked positive, then Ho rejected $\mathrm{Ha}$ accepted this means there is a significant influence between the variable ROI (X3) against changes in DPR variables.

d. From the results of partial test calculations obtained value $t$ arithmetic - $0.880<\mathrm{t}$ table 2.02108 and significant value of $0.384>0.05$, then Ho accepted $\mathrm{Ha}$ rejected this means there is no significant influence between variables NPM (X4) against the changes in DPR variables.

b) Test F (Test of influence simultaneously)

Based on the results of the F test above obtained F count is 3.948 larger than F table that is 2.60 with a significance level of 0.009 smaller than $\alpha=0.05$, then than $\mathrm{Ha}$ is accepted. The results of the above tests can be concluded simultaneously there is a significant influence between Return On Assets (ROA), Retun On Equity (ROE), Return On Investment (ROI), Net Profit
Margin (NPM) to Dividend Payout Ratio.

\section{c) Determination Coefficient Test $\left(\mathrm{R}^{2}\right)$}

Based on the summary output, it is known that the coefficient of determination ( $\mathrm{R}$ Square) is 0.283 (value 0.283 is the squaring of correlation coefficient or $\mathrm{R}$, that is $0,532 \times 0,532=0,283)$. The magnitude of the coefficient of determination ( $\mathrm{R}$ Square) 0.283 equals $28.3 \%$. This figure means that ROA, ROE, ROI and NPM affect the House of $28.3 \%$. While the rest $(100 \%-28.3 \%=71.7 \%)$ is influenced by other variables beyond this regression model. The magnitude of the

influence of these other variables is often

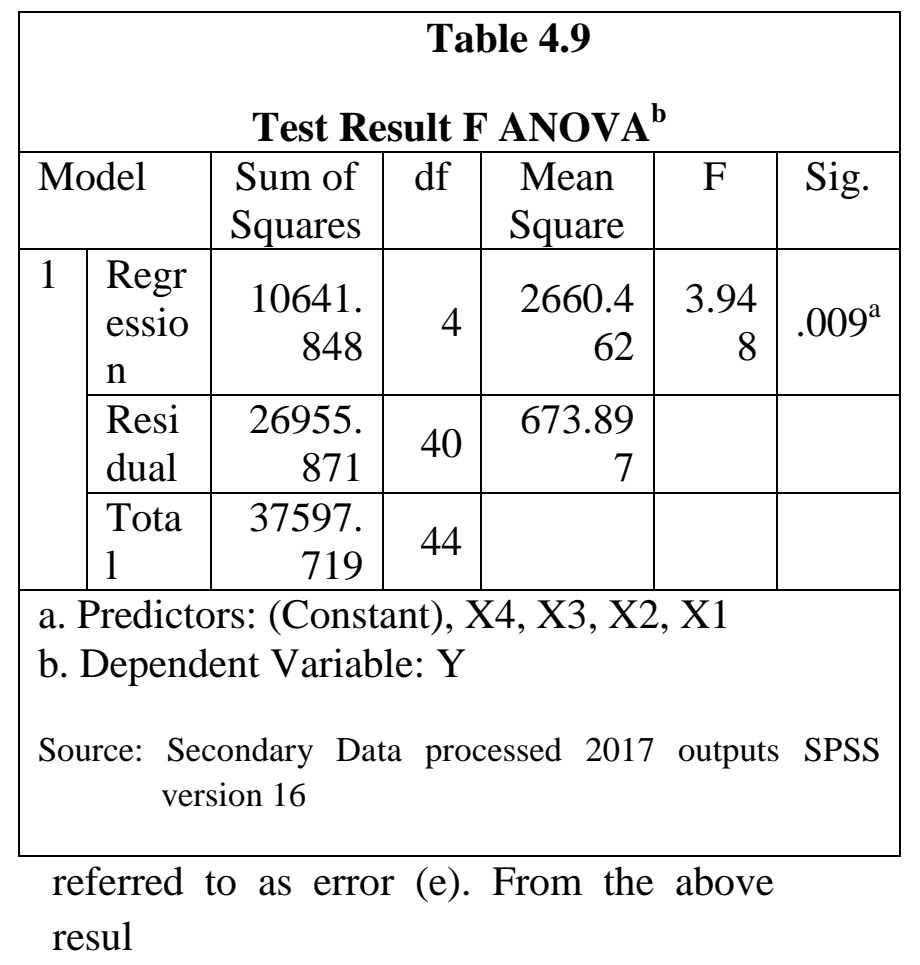


ISSN: 2614-1280, https://jurnal.stie-aas.ac.id/index.php/IJEBAR

ts can be concluded the value of $\mathrm{R}$ Square 0.283 is less close to 1 , then the effect of $\mathrm{X}$ to $\mathrm{Y}$ is not large.

\subsection{Discussion of Research Results}

a) Return On Assets

The first hypothesis states that the return on assets have a significant positive effect on the DPR. Testing this hypothesis shows that the variable ROA has no significant effect on the House.

b) Return On Equity

The second hypothesis states that the return on equity has a significant positive effect on the DPR. From the results of hypothesis testing using $t$ test obtained value $\mathrm{t}$ arithmetic - 0.371 < $t_{\text {table }} 2.02108$ and significant value of $0.713>0.05$. Means there is no significant effect between the change of ROE variable to the variable change of DPR so that the hypothesis is rejected.

c) Return On Investment

The third hypothesis states that the return on investment has a significant positive effect on the DPR. From the results of hypothesis testing using $t$ test obtained significance value of 0.008 smaller than the value of 0.05 so that this hypothesis is accepted.

d) Net Profit Margin

The fourth hypothesis states that Net Profit Margin has a significant positive effect on DPR. From the results of hypothesis testing using $t$ test obtained significant value of 0.384 greater than 0.05. Means there is no significant influence between the change of NPM variables to changes in DPR variables, so the hypothesis is rejected.

The fifth hypothesis states that there is a significant influence of Return On Assets, Return On Equity, Return On Investment and Net Profit Margin to Dividend Payout Ratio simultaneously. From the results of hypothesis testing using $\mathrm{F}$ test and determination test obtained value significance 0.009 smaller than $\alpha=0.05$, then than the hypothesis accepted. The results of this study showed that ROA, ROE, ROI and NPM together (simultaneously) have a significant effect on House of Representatives by $28.3 \%$. While the rest $(100 \%-28.3 \%=71.7 \%)$ is influenced by other variables beyond this regression model.

\section{CONCLUSIONS AND SUGGESTIONS}

\subsection{Conclusion}

a. Based on the results of the first hypothesis testing, it showed partially that ROA has no significant effect on the House, where the value of significance of 0.136 is greater than the value of 0.05 so that this hypothesis is rejected.

b. Based on the results of the second hypothesis testing, showed partially that ROE has no significant effect on the House, where the value of $t$ arithmetic 0.371 smaller than t table 2.02108 and significant value of 0.713 greater than 0.05 so the hypothesis is rejected .

c. Based on the results of the third hypothesis testing, ROI showed a significant positive partial effect on the House, which obtained a significance value of 0.008 smaller than the value of 0.05 so that this hypothesis is accepted.

d. Based on the results of the fourth hypothesis testing, it showed partially that NPM has no significant effect on Parliament, where the value of significant value of 0.384 is greater than 0.05 so the hypothesis is rejected.

e. Based on the results of the fifth hypothesis testing, in the simultaneous $\mathrm{F}$ test and the determination test shows 
International Journal of Economics, Business and Accounting Research (IJEBAR)

Peer Reviewed - International Journal

Vol-2, Issue-1, 2018 (IJEBAR)

ISSN: 2614-1280, https://jurnal.stie-aas.ac.id/index.php/IJEBAR

that the Return On Equity, Net Profit Margin, Return On Investment and Return On Assets simultaneously have significant effect on Dividend Payout Ratio.

f. The amount of influence on Return On Equity, Net Profit Margin, Return On Investment and Return On Assets to Dividend Payout Ratio simultaneously $28.3 \%$ while the remaining $71.7 \%$ influenced by other variables beyond this regression model.

\subsection{Suggestions}

a. This study only uses Dividend Payout Ratio to assess company performance. It is further expected to develop this research by assessing other financial ratios that can be used to assess company performance such as EPS, DER, CR, etc.

b. Other factors that affect the change of company performance should get attention before taking investment decisions. So it is not only financial ratios of profitability such as ROA, ROE, ROI and NPM, but also can use other ratios that may affect changes in company performance, such as Quick Ratio, Laverage, Institutional Ownership, Managerial Ownership.

\section{References}

Fahmi, Irham. (2011). Analisis Laporan Keuangan. Bandung: Alfabeta.

Bambang Riyanto. 2001. Dasar-dasar Pembelanjaan Perusahaan. BPFE, Yogyakarta.

Dwi Prastowo, dan Rifka Julianty. (2002). Analisis Laporan Keuangan: Konsep dan Aplikasi. Yogyakarta: AMP YKPN
Efni, Yulia. 2013. Analisis Kebijakan Pendanaan, Kepemilikan Manajerial dan Aliran Kas Bebas terhadap Kebijakan Dividen Pada Perusahaan Non Manufaktur yang Terdaftar di Bursa Efek Indonesia (BEI ). Jurnal.

Febrianti, Reni. (2014). Pengaruh Independensi, Due Professional Care dan Akuntabilitas Terhadap Kualitas Audit. Jurnal Akutansi. 3 (1). Padang.

Hanafi, (2004). Manajemen Keuangan. Yogyakarta: BPFE UGM.

Harahap. (2004). Analisis Kritis Atas Laporan Keuangan. Edisi Pertama. Cetakan Keempat. PT. Raja Grafindo Persada. Jakarta.

Ikatan Akuntan Indonesia. 2007. Standar Akuntansi Keuangan. Jakarta: Salemba Empat.

Jumingan. 2006. Analisa Laporan Keuangan. Jakarta: Bumi Aksara.

Mulyadi. 2001. Sistem Akuntansi Edisi Tiga. Jakarta : Salemba Empat.

Simamora. 2000. Basis Pengambilan Keputusan Bisnis. Salemba Empat. Jakarta.

S. Munawir. 2004. Analisis Laporan Keuangan, Edisi Ke-4, Liberty, Yogyakarta. Ikatan Akuntansi Indonesia (IAI). 2004. Pernyataan Standar Akuntansi Keuangan (PSAK ). Jakarta: Salemba Empat.

Srimindarti, C, 2006. Balanced Scorecard Sebagai Alternatif untuk Mengukur Kinerja, STIE Stikubank, Semarang. 